\title{
Seasonal variation of planktonic chrysophytes with special focus on Dinobryon
}

\author{
Christina Bock ${ }^{1 *}$, Ralph Medinger ${ }^{1,2}$, Steffen Jost $^{1}$, Roland Psenner ${ }^{2}$ \& Jens \\ BOENIGK $^{1}$
}

\author{
${ }^{1}$ Department of Biodiversity, University Duisburg-Essen, Universitätsstrasse 5, D-45117 Essen; \\ *Corresponding author e-mail: christina.bock@uni-due.de \\ ${ }^{2}$ Institute of Ecology, University of Innsbruck, Technikerstrasse 15, A-6020 Innsbruck
}

\begin{abstract}
The diversity of chrysophytes is often underestimated in morphological surveys because of the limited amount of detectable characters under the light microscope. Addressing biodiversity issues solely based on morphological characters is further problematic since molecular analyses revealed a huge genetic diversity within morphotypes, even showing polyphyly in some morphological defined species. In order to address the seasonal variations of chrysophytes, 10 samples were collected in 2007 from the oligotrophic lake Fuschlsee (Salzkammergut, Austria). By using Dinobryon as a case study, we compared different gene phylogenies of single cells of the 18S, ITS (including ITS1, 5.8S, partial ITS2) and the mitochondrial marker COI. No clear molecular phylogenetic separation between morphological identified cells of $D$. divergens and $D$. bavaricum could be accomplished based on the 18S rDNA sequences. ITS and COI sequence data revealed a higher genetic diversity then the $18 \mathrm{~S}$, with several independent lineages consisting of $D$. divergens cells. We further encountered divergent phylogenies by comparing 18S/ITS sequence data with COI data within D. pediforme, $D$. sociale and D. bavaricum lineages. By combining the results of the single cell approach with seasonal data based on 454 pyrosequencing, we addressed the question in how far one morphological species may dominate in the water column over the course of a single year. The results of the 454 pyrosequencing revealed that the $D$. divergens/D. bavaricum lineage shows the highest abundance from all Chrysophyceae/Synurophyceae and strong seasonal variations with peaks in May and October.
\end{abstract}

Key words: chrysophytes, Dinobryon, diversity, phylogeny, 454 pyrosequencing, single-cell PCR

\section{INTRODUCTION}

In the past, the exploration of protist diversity in lakes was either focused on microscopic determination of morphological characters (PADISÁK et al. 1998) or genetic surveys, by cloning and subsequent Sanger sequencing of selected clones (LeVÈVRe et al. 2008; Luo et al. 2011). Molecular investigations of different organismal groups revealed high phylogenetic diversity within one morphotype, showing the difficulties in addressing biodiversity issues based solely on morphological characters (BocK et al. 2011a; KRIENITZ et al. 2012; JenA et al. 2014). On the other hand, the ecology of many protists is still understudied. The same morphospecies may occur in nearby habitats, but is represented by different genotypes, demonstrating the inadequate knowledge of the ecology of many protist groups (Auinger et al. 2008; Pfandl et al. 2009; Bock et al. 2011b). Morphological convergence, often a response to habitat or herbivore pressure, further adds to the problem of assigning morphospecies to phylogenetic lineages. Specifically, simple body forms can lead to an underestimation of genetic diversity, as was shown in the example of the "green ball" Chlorella, which was detected in several independent phylogenetic lineages corresponding to different molecular defined genera and species (Huss et al. 1999; KRIENITZ et al. 2004; Neustupa et al. 2009) or for the colourless chrysophyte Spumella (Findenig et al. 2010). However, despite the general tendency to underestimate diversity in morphological analyses, the opposite, i.e. phenotypic plasticity as a response to habitat or herbivore pressure, has also been demonstrated for several algal species, like Scenedesmus or Micractinium (e.g. TraINOR 1998; LüRLING 1998, 1999; Luo et al. 2005, 2006).

Since the development of next-generation sequencing (NGS) technologies, the analyses of biodiversity shifted more to focusing on genetic variation within a given sample. Short sequences obtained by NGS technologies are searched against a nucleotide database (NCBI or similar databases). In undersampled/understudied groups of organisms, these searches obtain no or misleading results, as 
many of the sequences cannot be assigned to a specific name or group of organism since the molecular data is missing, or no taxonomic information is assigned to the reference sequences. An abundant group of mainly unicellular or colonial planktonic protists are chrysophytes (Chrysophyceae, Stramenopiles). They occur in marine and freshwater habitats and are one of the most prominent phytoplankton groups in alpine lakes (ToLOTTI et al. 2003; WiLlÉN 2003). They encompass varying nutritional strategies, including phototrophy, heterotrophy and mixotrophy, and are therefore important primary producers in aquatic systems as well as grazers of bacteria-sized microorganisms (Finlay \& EsteBAn 1998; BoENIGK \& ARNDT 2002). One dominant mixotrophic chrysophyte in temperate lakes is Dinobryon Ehrenberg 1834 (SILVER \& CHOCK 1986; Hitchman \& JONES 2000; WATSON et al. 2001; KamunnKe et al. 2007). This distinctive cylindrical, vase- or funnel-shaped chrysophyte was firstly described by Ehrenberg in 1834 on the basis of Dinobryon sertularia EHRENBERG and is mainly found in oligotrophic and phosphorus-poor freshwater habitats (LeE 1980; SANDGREN 1988; CANTER-Lund \& Lund 1995). The genus itself is known for its spring peak in the early stages of the thermal stratification in temperate lakes and forms a second, less abundant peak in late autumn (REYNOLD 1980; Armstrong 1985; TAS 2010). The members of this group are morphologically separated by the form and shape of the lorica consisting of cellulosic microfibrils. However, even for such morphologically distinct and abundant protist genera the taxonomic value of morphological criteria on the species level is doubtful (MEDINGER et al. 2011). Molecular phylogenies revealed that the distinct morphotype of Dinobryon divergens is either a polyphyletic cryptic species complex or comprises morphological variants of a much broader 'biological' species (Jost et al. 2010; Medinger 2011).

In order to address the seasonal variations of chrysophytes, 10 samples were collected from the oligotrophic lake Fuschlsee (Salzkammergut, Austria), from the time of ice brake throughout the summer period to the winter season. By using Dinobryon as a case study, we compared different gene phylogenies based on single cells and 454 pyrosequencing data to investigate how far one morphological species may dominate the water column over the year and the suitability of the V4 region as marker gene.

\section{Materials and Methods}

Sampling. The molecular diversity and seasonality of the chrysophytes (including Synurophyceae) of the oligotrophic Lake Fuschlsee, Salzkammergut, Austria was evaluated based on a regular sampling campaign in 2007 (MEDINGER et al. 2010; Nolte et al. 2010). Between March 2007 and October
2007 , integrated samples covering the upper $10 \mathrm{~m}$ of the water column within the pelagic zone were collected every three weeks (10 samples in total, starting in week 13 at the end of March). Samples were filtered onto $0.2 \mu \mathrm{m}$ polycarbonate filters, the filters air dried and frozen at $-80^{\circ} \mathrm{C}$ until DNA extraction for the high-throughput sequencing occurred. Additional samples were taken for single cell analysis with a $6 \mu \mathrm{m}$ plankton net. The net samples were immediately transferred into $100 \mathrm{ml}$ nontransparent flasks and preserved with Lugol's iodine solution ( $2 \%$ final concentration). Net-samples were stored at $4{ }^{\circ} \mathrm{C}$ in the dark until further processing and preparation for morphological analysis and single-cell PCR. Additionally, Lugol's iodine solution preserved Net-samples from the nearby lakes Loibersbacher Teiche (LO), Wallersee (Wa), Mondsee (Mo), Wolfgangsee (Wo), Grafenbergsee (GF) and Bad Heratingersee (He) were analyzed by light microscopy; if present, cells/colonies with Dinobryon morphology were picked for single cell analyses.

Sample preparation for Next Generation Sequencing and Bioinformatic analyses. Genomic DNA was extracted from the $0.2 \mu \mathrm{m}$ polycarbonate filters with the DNeasy Tissue kit (Qiagen Gmbh Hilden, Germany) and amplified by HPLC purified PCR primers for the V3-V4 region of the SSU rRNA gene (fw: 5'- ATTAGGGTTCGATTCCGGAGAGG-3', rv: 5'-CTGGAATTACCGCGGSTGCTG - 3') following the protocol of NoLTE et al. (2010). PCR products were pooled and sequenced on one full picotiterplate on a 454 Roche FLX sequencer. The quality filtering included adapter and primer clipping, removal of sequences that include uncertain bases (Ns), a quality score $<24$ when averaged across the read after clipping adapters and primers or a minimum sequence length below $200 \mathrm{bp}$ (including PCR primers) (for details see NOLTE et al. 2010; PANDEY et al. 2010). Taxonomic classification and bioinformatic analyses were done as already described by Nolte et al. (2010) and PAndey et al. (2010). Reads which were classified as Chrysophyceae or Synurophyceae according to NCBI blast search were extracted and further processed. This resulted in 293 different sequences of approximately $180 \mathrm{bp}$ lengths.

Standardization of reads and abundance data. In order to compare the abundance counts between samples taken at different times, the sequence count data were set to the same number by randomly selecting the equal number of sequences in each sample until the number from the date with the lowest amount of sequences were matched (for details see the already described protocol in NolTE et al. 2010).

Phylogenetic placement of the 454 reads and seasonal data. A dataset of 160 SSU rRNA gene reference sequences with 1218 bases, representing the major clades of the Chrysophyceae, was initially aligned using ClustalW (Thompson et al. 1994) and manually adjusted by eye. RAxML 7.2.7 with the General Time Reversible model of nucleotide substitution (Stamatakis et al. 2005) was used to create the phylogenetic reference tree (Fig. S1). The 293 different sequences from the 454 pyrosequencing ("query" sequences) were manually aligned and merged with the reference alignment. Query sequences were then placed on a phylogenetic tree by using pplacer v1.1 (MATSEN et al. 2010). Lineages containing only 454 reads were manually collapsed and combined to one lineage on a $99 \%$ similarity threshold. The corresponding phylogenetic tree was divided in two parts (Figs 1, S2, S3). The uncertainty of a placement was 
evaluated with the EDPL method (implemented in pplacer) using maximum likelihood and posterior probability for the weight. The EDPL is the expected distance between placement locations. The values are visualized on the phylogenetic tree in square brackets after the read ID.

Light microscopy. Aliquots of $10 \mathrm{ml}$ Lugol fixed samples were settled in Utermöhl chambers onto coverslips (UTERMÖHL 1958) and analyzed by light microscopy at a total magnification of 200 (Zeiss Axiovert200, Zeiss, Jena, Germany). The samples were scanned for Dinobryon cells and appropriate cells were documented with Nikon NIS Elements software and identified according to STARMACH (1985).

Single cell PCR. To obtain 18S, ITS (including ITS1, 5.8S, ITS2) and COI gene sequences from as many different Dinobryon cells as possible, we applied a modified multiplex single-cell PCR (SC PCR) approach after JosT et al. (2010). Briefly, Dinobryon colonies and single cells were isolated from plankton samples preserved with Lugol's iodine solution according to the protocol of AUINGER et al. (2008). The picked cells were washed with sterile medium to remove freely dissolved DNA from the sample (MEDINGER et al. 2010). The multiplex single-cell PCR followed the protocol of Jost et al. (2010), using the primers Eukf (5'GAAACTGCGAATGGCTCATTATATCAG - 3') (modified EK82f primer after AUINGER et al. 2008) and ITSJ1ar (5'- GCTTAAATTCAGCGGGTATTCTT - 3') (Jost unpublished) for the SSU-ITS2 fragment and Coxf (5'TCTAGTATATTAGGAACCACGATGTC - 3') and Cox1br (5'- ACGGTAAACATATGATGAGCCCAAAC - 3') for COI (Jost et al. 2010; Jost unpublished). Amplification of the COI gene of Dinobryon pediforme cells was carried out using DpedCO1f $\left(5^{\prime}\right.$ - GCGCAGCTTATGTATCCAGGTG $\left.3^{\prime}\right)$ and DpedCO1r (5'- CATAAGCCATGCCTAGATAGCC $-3^{\prime}$ ) (JosT unpublished). As this primer pair did not work in liaison with the primer targeting the ribosomal operon in the multiplex approach, we split the solution with the disrupted single cell and amplified the ribosomal operon and the COI separately for $D$. pediforme. The COI amplification failed for all $D$. sociale strains. NCBI accession numbers of the newly sequenced cells are provided in Table S1.

Phylogenetic analyses on SSU, ITS and COI on single cells. Three different alignments were constructed for the phylogenetic analyses with the newly obtained sequences and additional sequences obtained from NCBI (http://www. ncbi.nlm.nih.gov/) on the basis of previous publications (e.g. Jost et al. 2010; Medinger et al. 2010; SiLbERFELD et al. 2010; Klaveness et al. 2011). The sequences were initially aligned using ClustelW (Thомpson et al. 1994) and adjusted by eye using the SequentiX Alignment Editor (HePPERLE 2004). Ambiguous aligned regions were excluded from the alignment. The phylogeny of the $18 \mathrm{~S}$ (Fig. S4) was inferred from an aligned dataset including 129 chrysophycean sequences based on 1197 characters. Four sequences (Synchroma grande DQ788730, Leukarachnion sp. FJ356265, Nannochloropsis granulata JF489984, Picophagus flagellatus AF185051) were chosen as outgroup according to previous publications (PATIL et al. 1999; KLAVENESS et al. 2011). The concatenated 18S-ITS (including 18S, ITS1, 5.8S, ITS2) phylogeny (Fig. 2) was inferred from a partitioned dataset of 96 Dinobryon- sequences with 2012 bases. Ambiguous aligned regions were excluded from the alignment. The COI phylogeny (Fig. 3) was inferred from 141 genomic sequences with 567 characters. Since three sequences of Dinobryon pediforme (culture LO226KS, cells LO236_2, LO236_3) derivate strongly in their sequence from other chrysophytes, a NCBI blastn search for somewhat similar sequences were conducted and the resulted related sequences of the major clades of the Phaeophyceae were chosen to represent this group. The Dinobryon clusters were designated according to Jost et al. (2010).

Each phylogeny presented here was inferred by maximum likelihood settings using Treefinder (JовB et al. 2004). The most appropriate substitution models were estimated using the AICc criteria within Treefinder (for SSU: GTR $+\mathrm{I}+\mathrm{G}$ model; partitioned dataset: SSU: TN, ITS1: HKY, 5.8S: HKY, ITS2: J2; COI: HKY). Bayesian posterior probabilities (BPP) were calculated by using MrBayes version 3.1 (Ronquist \& Huelsenbeck 2003). For each presented tree, two runs with four chains of Markov chain Monte Carlo (MCMC) iterations were performed with tree sampling every 100 generations. The GTR $+\mathrm{G}$ model with gamma shape parameter and proportion of invariable sites were chosen for the datasets. For the partitioned dataset the parameters were unlinked and allowed to vary across the partitions. Tracer V1.4 (RAmbaut \& DRummond 2007) was used to check the stationary phase and to identify an appropriate burn in value. The first $25 \%$ of the trees were discarded as burn-in and $50 \%$ majority-rule consensus trees were calculated for posterior probabilities. To test the confidence of the tree topologies, bootstrap analyses were carried out for distance (neighbor joining, NJ; 1000 pseudoreplicates) and maximum parsimony analyses (MP, 1000 pseudoreplicates; with heuristic search options based on random taxon addition, tree-bisectionreconnection (TBR) branch swapping algorithm and Multrees option enabled) using PAUP*, portable version 4.0b10 (SwOFForD 2002), and for maximum likelihood using Treefinder (ML, 1000 pseudoreplicates; settings as described above), respectively.

\section{RESULTS}

Due to the phylogenetic placement of the 454 reads, huge seasonal variations could be observed for several lineages (see Figs 1, S2, S3). An alternate pattern occurred within the Paraphysomonadidae (ID 122, ID 127, ID 103); within lineages related to Apoika sp. (ID 6, ID 106); within Synurales (IDs 107, 28) and Chromulinales (IDs 51, 65). The highest abundance was observed for the ID 1 (Dinobryon divergens/ bavaricum lineage) within the Ochromonadales. The main peak occurred in the first third of the year, and a second peak in October. The same peaks could be observed on a smaller scale for the ID 58 within the Dinobryon sociale lineage. The results of the SC PCR and the corresponding phylogenies show that $D$. divergens contains a high genetic diversity based on ITS and COI data (Figs 2, 3). Divergent clustering could be observed for $D$. pediforme who clustered within the Phaeophyceae based on COI information. 


\section{Phylogenetic placement of 454 reads and seasonal abundance}

After the standardization of the reads, NCBI blast resulted in 27.698 sequence reads out of 139.318 reads which were classified as Chrysophyceae/ Synurophyceae as the nearest NCBI blast hit. These sequences were applied to a reference alignment (see reference tree Fig. S1) and phylogenetically placed on the ML phylogram by using the program pplacer v1.1 (MATSEn et al. 2010).

The reads clustered in all major clades of the Chrysophyceae (Figs 1, S2). In the applied abundance data, a recurring seasonal pattern for a broad range of phylogenetic lineages could be observed. Noticeable was an alternate occurrence of three lineages within the Paraphysomonadidae. Seq. ID 122 (related to Paraphysomonas bandaiensis) had its main peak in the first third of the year, intersecting with ID127, which last from May to July followed by ID 103. A similar pattern could be observed with reads closely related to Apoika sp. Seq. ID 29 had a total abundance above 1000 reads and occurred more or less stable from April to September. On top of that, the Seq. ID 6 and ID 106 alternated in so far, that ID 6 was found with high abundance from March to early May, replaced by high read counts of ID 106 from end of May to August (while ID 6 was absent) until it occurred again from September to October, where ID 106 was absent. A similar pattern was observed for the Synurales (IDs 107 and 28) and Chromulinales (IDs 51, 65). The sequence with the highest amount of reads was ID 1, clustering within the Ochromonadales, specifically within Dinobryon divergens/bavaricum lineage. It showed a seasonal pattern with high abundance in the first third of the year, decreasing during the summer time and high amount of reads at the end of the vegetation period. This applies on a smaller scale to the ID 58 within the $D$. sociale lineage.

\section{Morphological observations of single cells of Dinobryon species}

The isolated cells showed typical characters for members of the genus Dinobryon: Cells with two heterokont flagella, surrounded by a flasked-shaped lorica. They occurred in free living solitary or branched colonies. The following species were morphological determined:

Dinobryon bavaricum: Colonies narrow and long. The lorica is divided into two parts, one upper cylindrical part and a long lower, narrow pointed part. Lorica $40-71 \mu \mathrm{m}$ long in total. Lengths of the upper nearly cylindrical part $19-31 \mu \mathrm{m}$. The opening at the cylindrical part is $6.3-8.5 \mu \mathrm{m}$ wide, the lower end of the cylindrical part $6.1-8.5 \mu \mathrm{m}$ wide. The cells vary from $10.5-20 \times 4.8-7.3 \mu \mathrm{m}$.

Dinobryon divergens: Lorica curved, $37-50 \mu \mathrm{m}$ long. The lorica is divided into two parts: one upper cylindrical part and a short lower, pointed part. Lower part sometimes oblique pointed. Cylindrical part $15-33.5 \mu \mathrm{m}$ long, opening at the upper end $6.5-10 \mu \mathrm{m}$ wide, at the lower end 6.5-10.05 $\mu \mathrm{m}$. The cells range from $8.1-15.3 \times 4.2-7.1 \mu \mathrm{m}$.

Dinobryon sociale: Lorica conical, $28-45.8 \mu \mathrm{m}$ long. Lorica from the upper end gradually becoming narrow. Opening 7.1-9.2 $\mu \mathrm{m}$ wide. The cells range from 6.7$14 \times 4.5-6.2 \mu \mathrm{m}$.

Dinobryon pediforme: Similar to $D$. divergens. Lorica cylindrical with a oblique pointed tip. Lorica 17-21 $\mu \mathrm{m}$ long, Opening 4.7-6.9 $\mu \mathrm{m}$ wide, lower part 4.9-6.1 $\mu \mathrm{m}$ wide. Cells $6.1-12.3 \times 3.9-5.4 \mu \mathrm{m}$.

\section{Phylogenetic analyses on single cells}

The general order of the SSU phylogeny (Fig. S4) was congruent with previous publications (JOST et al. 2010; Klaveness et al. 2011). Dinobryon sequences formed a clade within the Ochromonadales. The Dinobryon-clade was subdivided into 4 different main lineages with different statistical support. The two SSU sequences of $D$. pediforme (strain LO226KS, cell LO236_1) formed a lineage next to previously published sequences of $D$. sertularia, $D$. cylindricum, D. sociale var. americana and D. cf. sociale (1.0 BPP and 100 bootstrap support for ML, MP, NJ). Another lineage consisted of newly sequenced $D$. sociale sequences. The last lineage comprised morphospecies of $D$. divergens and $D$. bavaricum. The lineage can be subdivided into two clusters of $D$. divergens (cluster 1 and cluster 2), one sequence of $D$. divergens with no affiliation and one cluster of $D$. bavaricum. The separation into these clusters, however, was statistically not or only slightly significant. The analyses of the concatenated set of SSU and ITS (including 5.8S) sequences (Fig. 2) showed the same pattern for the $D$. sociale and $D$. pediforme lineages as the SSU phylogeny, but a higher phylogenetic diversity for the $D$. bavaricum $/ D$. divergens lineage. This lineage contained the statistically highly supported D. divergens cluster 1 (1.0 BPP and 100 bootstrap support for ML, MP, NJ) which comprises single cell sequences from different sampled lakes. Next to it a D. bavaricum lineage clustered with high statistical support (1.0 BPP and 100 bootstrap support for ML, MP, NJ). Together they formed a clade with high statistical support for ML, but medium support for all other analyses (0.95 BPP, bootstrap support of 100 for ML, 74 for MP and 88 for $\mathrm{NJ}$ ). At the top the $D$. divergens cluster 2 could be divided into two lineages: one comprising 4 sequences originating from cells of the lake Grafenbergsee (GF39_1 - GF39_4) (1.0 BPP, 100 bootstrap support for ML, MP, NJ), and a second lineage with cell from different origins (1.0 BPP, 100 bootstrap support for ML, MP, NJ). By comparing the morphological observations of the investigated $D$. divergens cells with the phylogenies, no separation characters for phylogenetic lineages could be observed. 


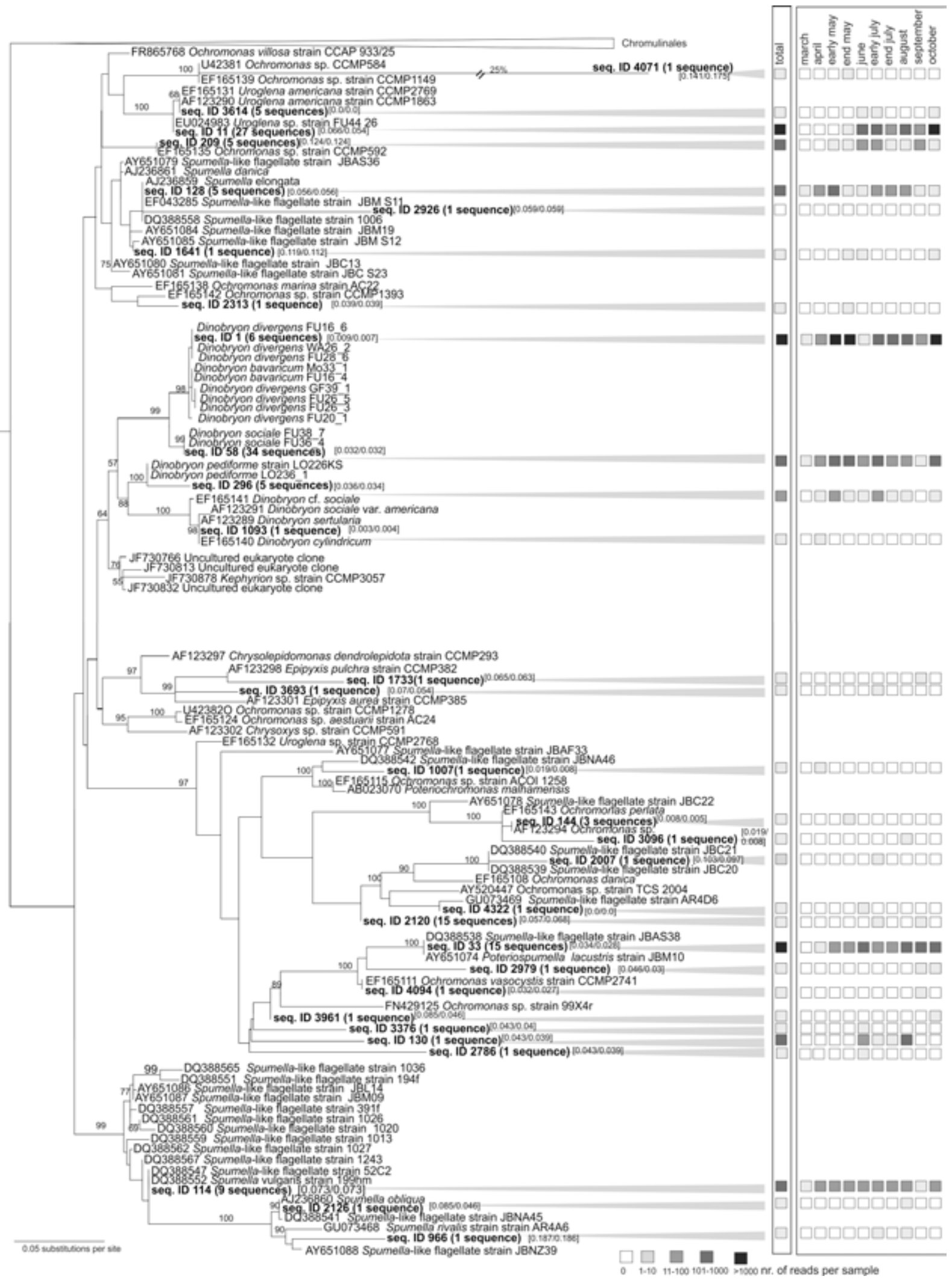

Fig. 1. Phylogenetic placement of 454 reads showing the Ochromonadales as part of a maximum likelihood reference phylogeny of the Chrysophyceae. For the whole phylogeny (see Figs S2 \& S3), 160 SSU rRNA gene sequences with 1218 bases were used as references and the phylogeny calculated with RAxML 7.2.7 with the GTR model of nucleotide substitution (STAMATAKIS et al. 2005). Query sequences were placed on the phylogeny by using pplacer v1.1 (MATSEN et al. 2010). The clade of the Ochromonadales was excluded manually. Values in square brackets after the 454 IDs represent the EDPL uncertainty values (first value is based on based on ML and second value based on Bayesian analyses). Lineages containing solely 454 reads were collapsed on a $99 \%$ pair wise distance threshold and the abundance data was summarized. To the right of the tree, the abundance data is summarized into columns of each sample date. The left-most column, "total", contains the sum of all standardized reads, followed by sequence counts for the different sampling dates. The zero abundance of some sequences is a result of the standardization of reads where some rare sequences where not chosen during the process of standardization. 


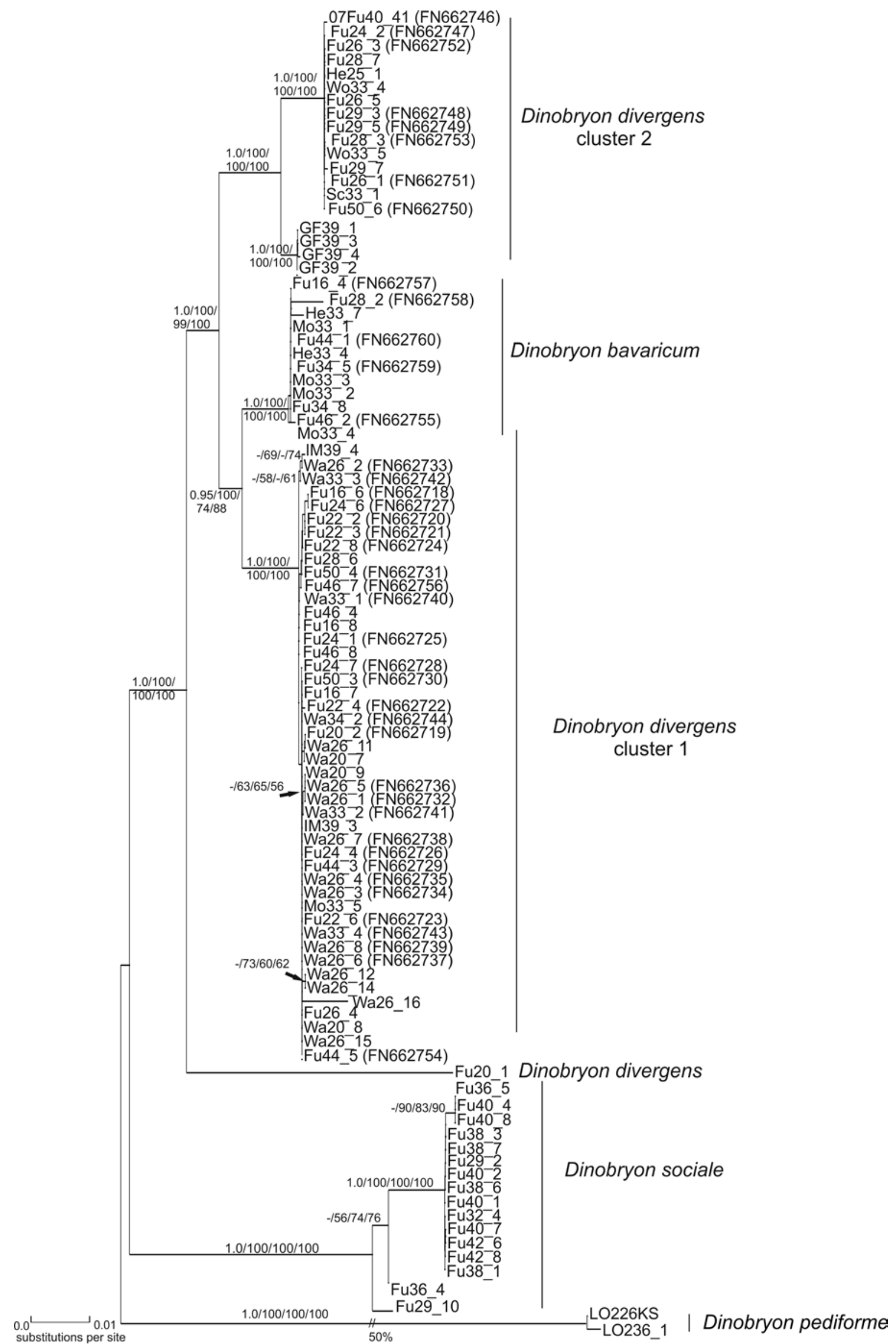


The investigated cells of the $D$. divergens cluster 1 and 2 show a both cases a broad range in terms of cell size and lorica size.

SSU/ITS and COI phylogeny (Figs 2, 3) were congruent for most of the investigated cells, i.e. sequences fell in the respective clusters. One exception occurred in the Dinobryon divergens cluster 2. The lineage containing GF39_1-GF39_4 formed according to their COI phylogeny a separate lineage outside the main $D$. divergens cluster 2 . Similar exceptions were noticeable for the cells Wa26 2 and Wa33 3. They belonged to the $D$. divergens cluster 1 according to $18 \mathrm{~S} / \mathrm{ITS}$ information, but formed a separate lineage according to COI information. Divergent phylogenies were observed for Fu34_8 (D. bavaricum morphotype, Fig. 4) and Fu29_2 (D. sociale, Fig. 5). Fu34 8 clustered according to the $18 \mathrm{~S}-$ ITS phylogeny (Fig. 2) within the Dinobryon bavaricum lineage, which was congruent with the morphology. According to the COI information, this cell clusters within the $D$. divergens cluster 2 (Fig. 3). Similarly, D. sociale Fu29_2 clustered in the $D$. sociale lineage according to the $18 \mathrm{~S}-\mathrm{ITS}$ phylogeny but in the $D$. divergens cluster 2 according to COI information. Huge discrepancies were also observed for the analyzed $D$. pediforme single cells (LO236_2, LO236_3) and one D. pediforme culture from the culture collection (strain LO226KS of the Laboratory Jens Boenigk, University Essen), all isolated from the lake Loibersbacher Teiche, Austria. According to $18 \mathrm{~S}$ and ITS analyses they belong to the Chrysophyceae. In contrast, no unambiguous position could be determined based on their COI phylogeny. A clear phylogenetic placement was not possible, due to lacking close relatives. However, all three sequences clustered together within the Phaeophyceae, near members of the Ralfsiales according to their COI gene phylogeny (Fig. 3). To confirm this phylogeny, we conducted a ML phylogeny based on their amino acid sequences and found similar results (for details about methods and results see Fig. S5 and corresponding legend).

\section{Discussion}

Seasonal shifts in plankton communities are widely documented in previous studies (BEAVER \& CHRISMAN 1989; PAdisÁk et al. 1998; GAEdKe \& WickHAm 2004). However, until now, many approaches consisted only of morphological surveys and neglected differences between phylogenetic lineages. Recent morphological work shows that many species, defined by morphology, are in fact polyphyletic, belonging to different phylogenetic lineages and cannot be separated by their morphology (KRIENITZ et al. 2010; FINDENIG et al. 2010; Bock et al. 2011a,b). As a consequence, morphological determination might not be sufficient for assessing diversity and seasonal shifts of aquatic systems. By using Lake Fuschlsee as an example for seasonal changes in plankton communities, our study, like two previous studies, focused on genetic differences within a plankton community during one year (MEDINGER et al. 2010; Nolte et al. 2010). Nolte et al. (2010) focused on the unpigmented flagellates affiliated with the Spumella morphotype. Several previous studies showed that Spumella-like strains cluster in several phylogenetic lineages and are most probably polyphyletic and cannot be separated by light microscopical characters (Boenigk et al. 2005; Findening et al. 2010). The molecular approach of NoLTE et al. (2010) revealed that Spumella-like organisms have seasonal abundance patterns that are consistent with the temperature preference of the reference strains (originating from different environments). The 454 reads associated with Spumella-like isolates from cold environments were more abundant in the first third of the year, while sequences associated with isolates from warmer environments were more frequent during the summer (for details see Nolte et al. 2010). This example shows the advantage of molecular tools like 454 sequencing in addressing ecological/diversity questions. In a morphological survey, Spumella-like flagellates would have probably been identified as a single species, and these interesting and ecological important shifts in the Spumella community might have been missed.

Our analyses of the 454 reads revealed that the $D$. divergens/D. bavaricum lineage showed the highest overall read number from all Chrysophyceae/ Synurophyceae but also strong seasonal variations. Several previous studies have shown that Dinobryon gains advantages due to its mixotrophic lifestyle when nutrients are limited (Pugnetti \& Bettinetti 1999; TAs et al. 2010). Although Dinobryon has a prominent chloroplast and is able to photosynthesize, the species also feeds on bacteria and plays a significant role in the aquatic food web due to their predation on bacteria (BIRD \& KALFF 1986; VeEN 1991). With a phosphor concentration of $5 \mathrm{mg} . \mathrm{m}^{-3}$, Lake Fuschlsee is a relatively phosphorous-poor inland water body (GALLER 2006). Similarly, Dinobryon in Lake Constance was shown exemplarily to gain competition advantages during the

Fig. 2. Maximum likelihood phylogeny based on a concatenated set of 18S-ITS rRNA (including 18S, ITS1, 5.8S and partial ITS2) gene sequences. The phylogeny was inferred from a partitioned dataset of 96 Dinobryon- sequences with 2012 bases of different Dinobryon single cells using Treefinder (JoBB et al. 2004) with the models SSU: TN, ITS1: HKY, 5.8S: HKY, ITS2: J2. Values at the nodes indicate statistical support estimated by four methods - Bayesian support (BPP), maximum likelihood (ML), maximum parsimony (MP) and neighbor joining (NJ). Hyphens indicate support below 50\% for ML, MP, NJ and below 0.95 for BPP. 


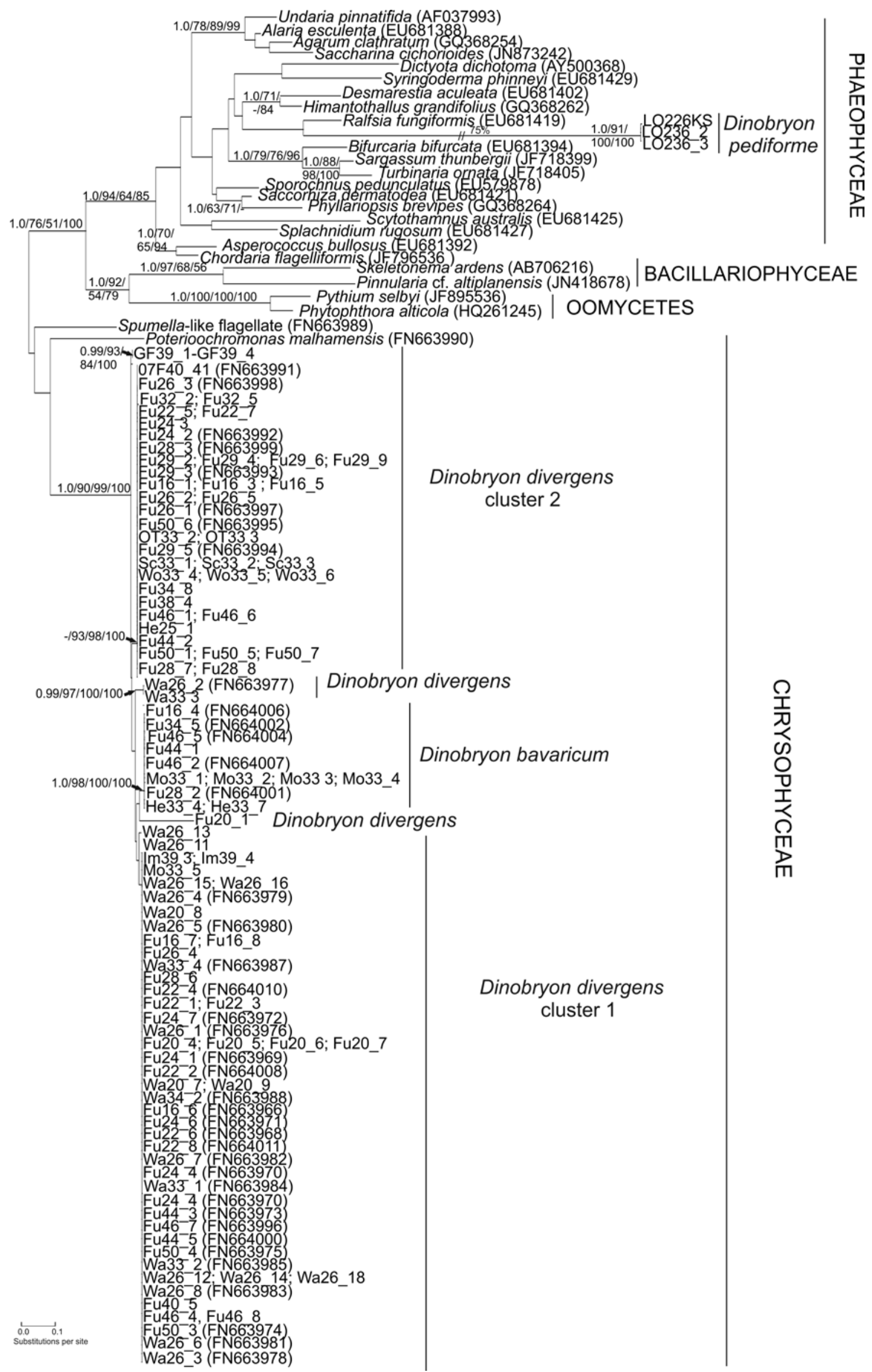


early stages of the year in oligotrophic, phosphorouspoor waters, due to its ability to obtain organic phosphorus from its bacterial prey (KAMJUNKE et al. 2007). This might be an explanation of the seasonal peaks of Dinobryon in our study as well.

The reliability of 454 pyrosequencing results depend on several factors: e.g. the taxonomic coverage of the DNA reference library used or the suitability of the chosen markers to distinguish between closely related species. To evaluate the resolution of the V4 region, we combined the information of the 454 phylogenetic placement with the Dinobryon singlecell analyses on different genes. No clear separation between $D$. divergens and $D$. bavaricum cells could be accomplished based on the SSU rDNA sequences, which is reflected in phylogenetic placement of the Seq. ID 6 within the cluster $D$. divergens /D. bavaricum (Fig. 1). Our results confirm the previous findings of Jost et al. (2010) that $D$. divergens contains a high genetic diversity based on ITS and COI data (Figs 2, 3 ). Both phylogenies resolve several clusters of $D$. divergens, intermixed with a $D$. bavaricum cluster, demonstrating, that the Dinobryon morphotype, especially $D$. divergens, is genetically more diverse than expected from its morphology. By comparing the molecular results with the morphological data on lorica and cell size and range, no clear pattern could be identified. The variation in size and shape was huge for all phylogenetic lineages, and no trend or separation characters could be identified. To make matters even more unclear, isolated strains of Dinobryon species change their lorica shape (especially the size) under culture conditions (personal observation) making the lorica a not reliable character to distinguish species. Whether we have polyphyletic cryptic species complexes or morphological variants of a much broader 'biological' species is open for discussion.

We also encountered divergent phylogenies within D. pediforme, D. sociale and D. bavaricum lineages. According to COI information, D. pediforme clustered within the Phaeophyceae and some $D$. sociale and $D$. bavaricum cells clustered within the $D$. divergens lineage respectively (controversy to their position based on 18S-ITS sequence data). This deviation of the COI phylogeny from the ITS phylogeny and the morphology is difficult to explain. As the results are not solely based on environmental samples but on one culture as well, we can, with near certainty, exclude factors like sequencing artifacts. Inconsistencies arising from a comparison of phylogenies based on different genes for the same taxa are known from several protist groups (SHALCHIAN-TABRIZI et al. 2006; Sтовск et al. 2008). Nevertheless, a proven explanation for such inconsistencies is still missing. Possible explanations include differential evolutionary rates of genes in different organisms (PHILIPPE et al. 2000), hybridization beyond species borders or lateral/ horizontal gene transfer. Lateral gene transfer, in particular, has been accepted for prokaryotic organisms for some time, but only recently have studies focused on the same phenomenon in eukaryotes (ANDERSSON et al. 2003; ANDERSSON 2005 and citations within). It is assumed that gene transfer occurs in protists with phagotrophic lifestyles in the same frequency as in

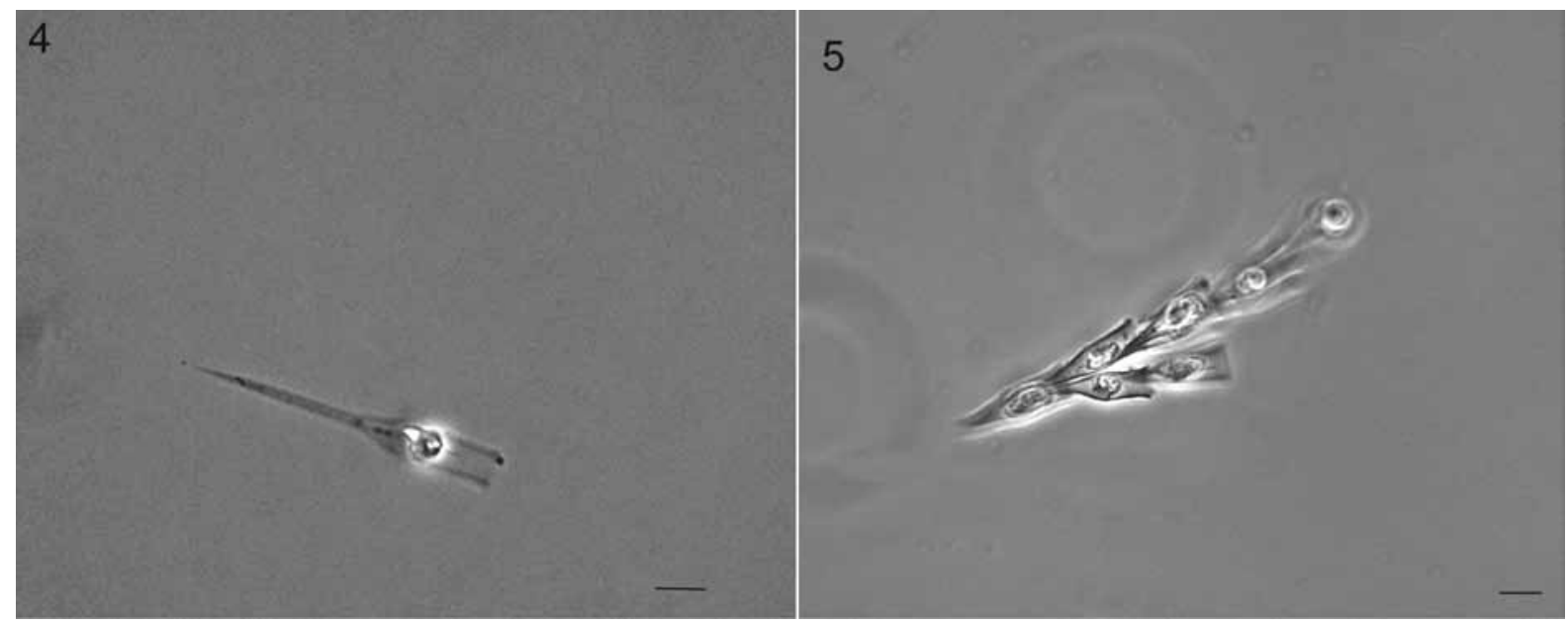

Fig. 4. Microphotograph of Dinobryon bavaricum Fu34_8. Scale bar 10 $\mu \mathrm{m}$. Fig.5. Microphotograph of Dinobryon sociale Fu29_2. Scale bar $10 \mu \mathrm{m}$.

Fig. 3. Maximum likelihood phylogeny of the nucleotide COI gene data of representatives of the Straminopiles based on 141 genomic sequences with 567 characters. Maximum likelihood was calculated using Treefinder (JoBB et al. 2004) with the HKY model. Values at the nodes indicate statistical support estimated by four methods - Bayesian posterior probability (BPP), maximum likelihood (ML), maximum parsimony (MP) and neighbor joining (NJ). Hyphens indicate support below 50\% for ML, MP, NJ and below 0.95 for BPP. Single cells originating from the same lake (and isolation date) which have the same sequence were summarized on one line to reduce the size of the figure. 
prokaryotic groups. Chrysophytes and specifically Dinobryon spp. are certainly mixotrophic and sexually reproducing. Thus, gene exchange by hybridization, as well as lateral gene transfer from ingested food items, may possibly play a role. Further, lateral gene transfer by viral vectors may also occur. Nevertheless, the COI placement of $D$. pediforme within the Phaeophyceae remains speculative as these organisms live in different habitats. Nevertheless, as this result was obtained independently not only from several single cells but also from mono-algal cultures, we can exclude contaminations with certainty. In concert with other deviating phylogenies within the chrysophytes, e.g. for colourless strains (STOECK et al. 2008) and other Dinobryon strains (this study), these results indicate that further broad-scale analyses of potential horizontal gene transfers in protists are needed. This and the cited studies suggest that chrysophytes might be a particularly well-suited target group for such work.

\section{ACKNOWLEDGEMENTs}

We thank the DFG for financial support (DFG project BO 3245/3-1 and BO 3245/2-1). This work resulted into a $\mathrm{PhD}$ degree (AFR 07/083) and we would like to acknowledge the support by the National Research Fund of Luxembourg (FNR) with its AFR Grant Scheme. We thank Edvard Glücksman and an unknown reviewer for helpful comments on the manuscript.

\section{RefERENCES}

ANDERSSON, J.O. (2005): Lateral gene transfer in eukaryotes. - Cell. Mol. Life Sci. 62: 1182-1197.

Andersson, J.O.; SJogren, A.M.; Davis, L. a. M.; Embley, T.M. \& Roger, A.J. (2003): Phylogenetic analyses of diplomonad genes reveal frequent lateral gene transfers affecting eukaryotes. - Curr. Biol. 13: 94 104.

Armstrong, G.D. (1985): Colonies as defense in the freshwater phytoplankton genus Dinobryon. University of British Columbia, Vancouver.

Auinger, B.M.; Pfandl, K. \& Boenigk, J. (2008): Improved methodology for identification of protists and microalgae from plankton samples preserved in Lugol's iodine solution: Combining microscopic analysis with single-cell PCR. - Appl. Environ. Microbiol. 74: 2505-2510.

Beaver, J.R. \& Crisman, T.L. (1989): Analysis of the community structure of planktonic ciliated Protozoa relative to trophic State in Florida Lakes. Hydrobiologia 174: 177-184.

BIRD, D.F. \& KALFF, J. (1986): Bacterial grazing by planktonic lake algae. - Science 231: 493-495.

Bock, C.; Krienitz, L. \& Pröschold, T. (2011): Taxonomic reassessment of the genus Chlorella (Trebouxiophyceae) using molecular signatures (barcodes), including description of seven new species. - Fottea 11: 293-312.

Bock, C.; Pröschold, T. \& Krienitz, L. (2011): Updating the genus Dictyosphaerium and description of
Mucidosphaerium gen. nov. (Trebouxiophyceae) based on morphological and molecular data.- J. Phycol. 47: 638-652.

BoENIGK, J. \& ARNDT, H. (2002): Bacterivory by heterotrophic flagellates: community structure and feeding strategies. - Antonie Van Leeuwenhoek International Journal of General and Molecular Microbiology 81: 465-480.

Boenigk, J.; Pfandl, K.; Stadler, P. \& Chatzinotas, A. (2005): High diversity of the 'Spumella-like' flagellates: an investigation based on the SSU rRNA gene sequences of isolates from habitats located in six different geographic regions. - Environ. Microbiol. 7: 685-697.

CAnTer-Lund, H. \& Lund, J.W.G. (1995): Freshwater algae: Their microscopic world explored. - 360 pp., Bristol, Biopress Ltd.

Ehrenberg, C.G. (1834): Dritter Beitrag zur Erkenntniss grosser Organisation in der Richtung des kleinsten Raumes. - Abhandlungen der Königlichen Akademie der Wissenschaften 1833: 145-336

Findenig, B.M.; Chatzinotas, A. \& Boenigk, J. (2010): Taxonomic and ecological characterization of stomatocysts of Spumella-like flagellates (Chrysophyceae). - J. Phycol. 46: 868-881.

Finlay, B.J. \& Esteban, G.F. (1998): Freshwater Protozoa: Biodiversity and ecological function. - Biodivers. Conserv. 7: 1163-1186.

Gaedke, U. \& Wickham, S.A. (2004): Ciliate dynamics in response to changing biotic and abiotic conditions in a large, deep lake (Lake Constance). - Aquat. Microb. Ecol. 34: 247-261.

GALLER, J. (2006): Eutrophierung: Ursachen und Maßnahmen. - 23 pp., Landwirtschaftskammer Salzburg

Hepperle, D. (2004): SequentiX Alignment Editor: Distributed by Author.

Hitchman, R.B. \& Jones, H.L.J. (2000): The role of mixotrophic protists in the population dynamics of the microbial food web in small artificial pond. Freshw. Biol. 43: 231-241.

Huss, V. a. R.; Frank, C.; Hartmann, E.C.; Hirmer, M.; Kloboucek, A.; Seidel, B.M.; Wenzeler, P. \& Kessler, E. (1999): Biochemical taxonomy and molecular phylogeny of the genus Chlorella sensu lato (Chlorophyta). - J. Phycol. 35: 587-598.

Jena, M.; Bock, C.; Behera, C.; Adhikary, S.P. \& Krienitz, L.(2014): Strain survey on three continents confirms the polyphyly of the genus Pediastrum (Hydrodictyaceae, Chlorophyceae). - Fottea 14: 63-76.

Jobb, G.; Von Haeseler, A. \& Strimmer, K. (2004): TREEFINDER: a powerful graphical analysis environment for molecular phylogenetics. - BMC Evol. Biol. 4.

Jost, S.; Medinger, R. \& Boenigk, J. (2010): Cultivationindependent species identification of Dinobryon species (Chrysophyceae) by means of multiplex single-cell PCR. - J. Phycol. 46: 901-906.

Kamjunke, N.; Henrichs, T. \& Gaedke, U. (2007): Phosphorus gain by bacterivory promotes the mixotrophic flagellate Dinobryon spp. during reoligotrophication. - J. Plankton Res. 29: 39-46.

Klaveness, D.; Brate, J.; Patil, V.; Shalchian-Tabrizi, K.; Kluge, R.; Gislerod, H.R. \& JAKOBSEN, K.S. (2011): The $18 \mathrm{~S}$ and $28 \mathrm{~S}$ rDNA identity and phylogeny of 
the common lotic chrysophyte Hydrurus foetidus. Eur. J. Phycol. 46: 282-291.

Krienitz, L.; Bock, C.; DadheEch, P.K. \& Pröschold, T. (2011): Taxonomic reassessment of the genus Mychonastes (Chlorophyceae, Chlorophyta) including the description of eight new species. Phycologia 50: 89-106.

Krienitz, L.; Bock, C.; Kotut, K. \& Pröschold, T. (2012): Genotypic diversity of Dictyosphaeriummorphospecies (Chlorellaceae, Trebouxiophyceae) in African inland waters, including the description of four new genera. Fottea, 12: 231-253.

Krienitz, L.; Bock, C.; Luo, W. \& Pröschold, T. (2010): Polyphyletic Origin of the Dictyosphaerium Morphotype within Chlorellaceae (Trebouxiophyceae). - J. Phycol. 46: 559-563.

Krienitz, L.; Hegewald, E.H.; Hepperle, D.; Huss, V. a. R.; Rohr, T. \& Wolf, M. (2004): Phylogenetic relationship of Chlorella and Parachlorella gen. nov. (Chlorophyta, Trebouxiophyceae). - Phycologia 43: 529-542.

Lee, R.E. (1980): Phycology. 1st ed. - 478 pp., New York, Cambridge University Press.

Lefèvre, E.; Roussel, B.; Amblard, C. \& Sime-Ngando, T. (2008): The molecular diversity of freshwater picoeukaryotes reveals high occurrence of putative parasitoids in the plankton. - Plos One 3: e2324. doi:10.1371.

Luo, W., Bock, C., Li, H.R., Padisak, J. \& Krienitz, L. (2011): Molecular and microscopic diversity of planktonic eukaryotes in the oligotrophic Lake Stechlin (Germany). - Hydrobiologia 661: 133-143.

Luo, W.; Krienitz, L.; Pflugmacher, S. \& Walz, N. (2005): Genus and species concept in Chlorella and Micractinium (Chlorophyta, Chlorellaceae): genotype versus phenotypical variability under ecosystem conditions. - Verh. Internat. Verein. Limnol. 29: 170-173.

Luo, W.; Pflugmacher, S.; Pröschold, T.; Walz, N. \& KrienitZ, L. (2006): Genotype versus phenotype variability in Chlorella and Micractinium (Chlorophyta, Trebouxiophyceae). - Protist 157: 315-333.

LÜRLING, M. (1998): Effect of grazing-associated infochemicals on growth and morphological, development in Scenedesmus acutus (chlorophyceae). - J. Phycol. 34: 578-586.

LÜRLING, M. (1999): Grazer-induced coenobial formation in clonal cultures of Scenendesmus obliquus (Chlorococcales, Chlorophyceae). - J. Phycol. 35: 19-23.

Matsen, F.A.; Kodner, R.B. \& Armbrust, E.V. (2010): pplacer: linear time maximum-likelihood and Bayesian phylogenetic placement of sequences onto a fixed reference tree. - BMC Bioinformatics 11.

Medinger, R. (2011): Diversity and distribution estimates with special focus on the chrysophyte Dinobryon [PhD thesis]. - 38 pp., University of Innsbruck, Insbruck.

Medinger, R.; Nolte, V.; Pandey, R.V.; Jost, S.; Ottenwalder, B.; Schlotterer, C. \& Boenigk, J. (2010): Diversity in a hidden world: potential and limitation of next-generation sequencing for surveys of molecular diversity of eukaryotic microorganisms. - Mol. Ecol. 19: 32-40.
Neustupa, J.; NĚmcová, Y.; Eliás, M. \& ŠKKaloud, P. (2009): Kalinella bambusicola gen. et sp. nov. (Trebouxiophyceae, Chlorophyta), a novel coccoid Chlorella-like subaerial alga from Southeast Asia. Phycol. Res. 57: 159-169.

Nolte, V.; Pandey, R.V.; Jost, S.; Medinger, R.; Ottenwalder, B.; Boenigk, J. \& Schlotterer, C. (2010): Contrasting seasonal niche separation between rare and abundant taxa conceals the extent of protist diversity. - Mol. Ecol. 19: 2908-2915.

PadisÁk, J.; Krienitz, L.; Scheffler, W.; Koschel, R.; Kristiansen, J. \& GrigorszKKy, I. (1998): Phytoplankton succession in the oligotrophic Lake Stechlin (Germany) in 1994 and 1995. Hydrobiologia 370: 179-197.

Pandey, R.V.; Nolte, V. \& Schlötterer, C.(2010): CANGS: a user-friendly utility for processing and analyzing 454 GS-FLX data in biodiversity studies. - BMC Res Notes 3:3.

Patil, V.; Brate, J.; Shalchian-Tabrizi, K. \& Jakobsen, K.S. (2009): Revisiting the phylogenetic position of Synchroma grande. - J. Eukaryot. Microbiol. 56: 394-396.

Pfandl, K.; Chatzinotas, A.; Dyal, P. \& Boenigk, J. (2009): SSU rRNA gene variation resolves population heterogeneity and ecophysiological differentiation within a morphospecies (Stramenopiles, Chrysophyceae). - Limnol. Oceanogr. 54: 171-181.

Philippe, H.; Lopez, P.; Brinkmann, H.; Budin, K.; Germot, A.; Laurent, J.; Moreira, D.; Muller, M. \& Le GuYADER, H. (2000): Early-branching or fastevolving eukaryotes? An answer based on slowly evolving positions. - P. Roy. Soc. B-Biol. Sci. 267: 1213-1221.

Pugnetti, A. \& Bettinetti, R. (1999): Biomass and species structure of the phytoplankton of an high mountain lake (Lake Paione Superiore, Central Alps, Italy). - J. Limnol. 58: 127-130.

Rambaut A. \& Drummond, A.J. (2007): Tracer v1.4. Available from http://beast.bio.ed.ac.uk/Tracer.

ReYNOLDS, C.S. (1980): Phytoplankton Assemblages and their periodicity in stratifying lake systems. - Holarctic Ecol. 3: 141-159.

Ronquist, F. \& HuElsenbeck, J.P. (2003): MrBayes 3: Bayesian phylogenetic inference under mixed models. - Bioinformatics 19: 1572-1574.

SANDGREN, C.D. (1988): The ecology of chrysophyte flagellates: their growth and perennation strategies as freshwater phytoplankton - In: SANDGREN, C.D. (ed.): Growth and Reproductive Strategies of Freshwater Phytoplankton. - pp. 9-104, Cambridge University Press, Cambridge.

Shalchian-Tabrizi, K.; Eikrem, W.; Klaveness, D.; Vaulot, D.; Minge, M.A.; Gall, F.L.; Romari, K.; Throndsen, J.; Botnen, A.; Massana, R.; Thomsen, H.A. \& JAKOBSEN, K.S. (2006): Telonemia, a new protist phylum with affinity to chromist lineages. - Proc. R. Soc. 273: 1833-1842.

Silberfeld, T.; Leigh, J. W.; Verbruggen, H.; Cruaud, C.; De Reviers, B. \& Rousseau, F. (2010): A multilocus time-calibrated phylogeny of the brown algae (Heterokonta, Ochrophyta, Phaeophyceae): Investigating the evolutionary nature of the "brown algal crown radiation". - Mol. Phylogen. Evol. 56: 659-674. 
Siver, P.A. \& CHock, J.S. (1986): Phytoplankton dynamics in a chrysophycean lake. - In: KRISTIANSEN, J. \& ANDERSEN, R.A. (eds): Chrysophytes: aspects and problems. - pp. 165-183, Cambridge University Press - Cambridge.

Stamatakis, A.; Ludwig, T. \& Meier, H. (2005): RAxMLIII: a fast program for maximum likelihoodbased inference of large phylogenetic trees. Bioinformatics 21: 456-463.

Starmach, K. (1985): Chrysophyceae und Haptophyceae. - 515 pp., Gustav Fischer Verlag, Stuttgart \& New York.

Stoeck, T.; Jost, S. \& Boenigk, J. (2008): Multigene phylogenies of clonal Spumella-like strains, a cryptic heterotrophic nanoflagellate, isolated from different geographical regions. - Int. J. Syst. Evol. Microbiol. 58: 716-724.

SwOFFord, D.L. (2002): Phylogenetic analysis using parsimony (* and other methods), version 4.0b 10. Massachusetts: Sinauer Associates, Sunderland.

TAs, B.; Gonulol, A. \& TAS, E. (2010): Seasonal dynamics and biomass of mixotrophic flagellate Dinobryon sertularia Ehrenberg (Chrysophyceae) in Derbent Reservoir (Samsun, Turkey). - Turkish J. Fish. Aquat. Sci. 10: 305-313.

Thompson, J.D.; Higgins, D.G. \& Gibson, T.J. (1994): Clustal-W - Improving the Sensitivity of Progressive Multiple Sequence Alignment through Sequence Weighting, Position-Specific Gap Penalties and Weight Matrix Choice. - Nucl. Acids Res. 22: 4673 4680.

Tolotti, M.; Thies, H.; Cantonati, M.; Hansen, C.M.E. \& THALER, B. (2003): Flagellate algae (Chrysophyceae, Dinophyceae, Cryptophyceae) in 48 high mountain lakes of the Northern and Southern slope of the Eastern Alps: biodiversity, taxa distribution and their driving variables. - Hydrobiologia 502: 331-348.

TrainOR, F.R. (1998): Biological aspects of Scenedesmus (Chlorophyceae)-phenotypic plasticity. - Nova Hedwigia, Beiheft 117: 1-367.

Veen, A. (1991): Ecophysiological studies on the phagotrophic phytoflagellate Dinobryon divergens Imhof. [PhD thesis]. - 125 pp., Universiteit van Amsterdam, Amsterdam.

Watson, S.B.; Satchwill, T.; Dixon, E. \& McCauley, E. (2001): Underice blooms and source-water odour in a nutrient-poor reservoir: biological, ecological and applied perspectives. - Freshw. Biol. 46: 1553-1567.

WILLEN, E. (2003): Dominance patterns of planktonic algae in Swedish forest lakes. - Hydrobiologia 502: 315-324.
Supplementary material

the following supplementary material is available for this article:

Table S1. Newly obtained accession numbers for the analyzed regions.

Fig. S1. Maximum likelihood phylogeny based on SSU rRNA of the chryosphytes used as a reference tree for the phylogenetic placement of the 454 reads.

Fig. S2. Phylogenetic placement of 454 reads (293 different sequences, each reads contained approx. $180 \mathrm{bp}$ ) on a maximum likelihood reference tree of the Chrysophyceae.

Fig. S3. The figure shows the Ochromonadales as part of the phylogenetic placement of the 454 reads within the Chrysophyceae (see Fig. S2).

Fig.S4. Maximum likelihood phylogeny based on $18 \mathrm{~S}$ rRNA gene data of Chrysophyceae, including single cell sequences of different Dinobryon cells.

Fig. S5. Maximum likelihood phylogeny based on COI amino acids information. Alignment consisted of 141 taxa with 189 characters.

(http://fottea.czechphycology.cz/contents)

(C) Czech Phycological Society (2014)

Received March 18, 2014

Accepted June 5, 2014 

Table S1. Newly obtained accession numbers for the analyzed regions.

\begin{tabular}{|c|c|c|c|}
\hline & Morphological designation & $\begin{array}{l}\text { NCBI Acc.nr SSU, } \\
\text { ITS1,5.8S,ITS2 }\end{array}$ & NCBI Acc.nr COI \\
\hline Fu34_8 & Dinobryon bavaricum & KJ579311 & KJ579375 \\
\hline Fu44_1 & Dinobryon bavaricum & & KJ579422 \\
\hline HE33_4 & Dinobryon bavaricum & KJ579312 & KJ579387 \\
\hline HE33_7 & Dinobryon bavaricum & KJ579313 & KJ579388 \\
\hline Mo33_1 & Dinobryon bavaricum & KJ579314 & KJ579399 \\
\hline Mo33_2 & Dinobryon bavaricum & KJ579315 & KJ579400 \\
\hline Mo33_3 & Dinobryon bavaricum & KJ579316 & KJ579401 \\
\hline Mo33_4 & Dinobryon bavaricum & KJ579317 & KJ579402 \\
\hline Fu16_3 & Dinobryon divergens & & KJ579349 \\
\hline Fu16_1 & Dinobryon divergens & & KJ579348 \\
\hline Fu16_5 & Dinobryon divergens & & KJ579350 \\
\hline Fu16_7 & Dinobryon divergens & KJ579318 & KJ579351 \\
\hline Fu16_8 & Dinobryon divergens & KJ579319 & KJ579352 \\
\hline $\mathrm{Fu} 20 \_1$ & Dinobryon divergens & KJ579320 & KJ579353 \\
\hline Fu20_4 & Dinobryon divergens & & KJ579354 \\
\hline Fu20_5 & Dinobryon divergens & & KJ579355 \\
\hline Fu20_6 & Dinobryon divergens & & KJ579356 \\
\hline $\mathrm{Fu} 20 \_7$ & Dinobryon divergens & & KJ579357 \\
\hline $\mathrm{Fu} 22 \_3$ & Dinobryon divergens & & KJ579359 \\
\hline $\mathrm{Fu} 22 \_1$ & Dinobryon divergens & & KJ579358 \\
\hline Fu22_5 & Dinobryon divergens & & KJ579360 \\
\hline Fu22_7 & Dinobryon divergens & & KJ579361 \\
\hline Fu24_3 & Dinobryon divergens & & KJ579362 \\
\hline Fu26_2 & Dinobryon divergens & & KJ579363 \\
\hline Fu26_4 & Dinobryon divergens & KJ579321 & KJ579364 \\
\hline Fu26_5 & Dinobryon divergens & KJ579322 & KJ579365 \\
\hline Fu28_6 & Dinobryon divergens & KJ579323 & KJ579366 \\
\hline Fu28_7 & Dinobryon divergens & KJ579324 & KJ579367 \\
\hline Fu28_8 & Dinobryon divergens & & KJ579368 \\
\hline $\mathrm{Fu} 29 \_4$ & Dinobryon divergens & & KJ579370 \\
\hline Fu29_6 & Dinobryon divergens & & KJ579371 \\
\hline Fu29_7 & Dinobryon divergens & KJ579325 & \\
\hline Fu29_9 & Dinobryon divergens & & KJ579372 \\
\hline Fu32_2 & Dinobryon divergens & & KJ579373 \\
\hline Fu32_5 & Dinobryon divergens & & KJ579374 \\
\hline Fu38_4 & Dinobryon divergens & & KJ579376 \\
\hline Fu40_5 & Dinobryon divergens & & KJ579377 \\
\hline
\end{tabular}




\begin{tabular}{|c|c|c|c|}
\hline Fu44_2 & Dinobryon divergens & & KJ579378 \\
\hline Fu46_1 & Dinobryon divergens & & KJ579379 \\
\hline Fu46_4 & Dinobryon divergens & KJ579326 & KJ579380 \\
\hline Fu46_6 & Dinobryon divergens & & KJ579381 \\
\hline Fu46_8 & Dinobryon divergens & KJ579327 & KJ579382 \\
\hline Fu50_1 & Dinobryon divergens & & KJ579383 \\
\hline Fu50_5 & Dinobryon divergens & & KJ579384 \\
\hline Fu50_7 & Dinobryon divergens & & KJ579385 \\
\hline GF39_1 & Dinobryon divergens & KJ579328 & KJ579393 \\
\hline GF39_2 & Dinobryon divergens & KJ579329 & KJ579394 \\
\hline GF39_3 & Dinobryon divergens & KJ579330 & KJ579395 \\
\hline GF39_4 & Dinobryon divergens & KJ579331 & KJ579396 \\
\hline HE25_1 & Dinobryon divergens & KJ579332 & KJ579386 \\
\hline IM39_3 & Dinobryon divergens & KJ579333 & KJ579397 \\
\hline IM39_4 & Dinobryon divergens & KJ579334 & KJ579398 \\
\hline MO33_5 & Dinobryon divergens & KJ579335 & KJ579403 \\
\hline OT33_3 & Dinobryon divergens & & KJ579416 \\
\hline OT33_2 & Dinobryon divergens & & KJ579414 \\
\hline Sc33_3 & Dinobryon divergens & & KJ579418 \\
\hline Sc33_1 & Dinobryon divergens & KJ579336 & KJ579404 \\
\hline Sc33_2 & Dinobryon divergens & & KJ579415 \\
\hline Wa20_7 & Dinobryon divergens & KJ579337 & KJ579390 \\
\hline Wa20_8 & Dinobryon divergens & KJ579338 & KJ579389 \\
\hline Wa20_9 & Dinobryon divergens & KJ579339 & KJ579391 \\
\hline Wa26_18 & Dinobryon divergens & & KJ579411 \\
\hline Wa26_11 & Dinobryon divergens & KJ579340 & KJ579405 \\
\hline Wa26_12 & Dinobryon divergens & KJ579341 & KJ579406 \\
\hline Wa26_13 & Dinobryon divergens & & KJ579407 \\
\hline Wa26_14 & Dinobryon divergens & KJ579342 & KJ579408 \\
\hline Wa26_15 & Dinobryon divergens & KJ579343 & KJ579409 \\
\hline Wa26_16 & Dinobryon divergens & KJ579344 & KJ579410 \\
\hline Wa26_6 & Dinobryon divergens & & KJ579392 \\
\hline Wo33_4 & Dinobryon divergens & KJ579346 & KJ579412 \\
\hline Wo33_5 & Dinobryon divergens & KJ579345 & KJ579413 \\
\hline Wo33_6 & Dinobryon divergens & & KJ579417 \\
\hline LO226KS & Dinobryon pediforme & KJ913667 & KJ579421 \\
\hline LO236_1 & Dinobryon pediforme & KJ579347 & \\
\hline LO236_2 & Dinobryon pediforme & & KJ579419 \\
\hline
\end{tabular}


Table S1 Cont.

KJ579420

\begin{tabular}{|c|c|c|c|}
\hline Fu29_10 & Dinobryon sociale & KJ579296 & \\
\hline Fu29_2 & Dinobryon sociale & KJ579295 & KJ579369 \\
\hline Fu32_4 & Dinobryon sociale & KJ579297 & \\
\hline Fu36_4 & Dinobryon sociale & KJ579298 & \\
\hline Fu36_5 & Dinobryon sociale & KJ579299 & \\
\hline Fu38_1 & Dinobryon sociale & KJ579300 & \\
\hline Fu38_3 & Dinobryon sociale & KJ579301 & \\
\hline Fu38_6 & Dinobryon sociale & KJ579302 & \\
\hline Fu38_7 & Dinobryon sociale & KJ579303 & \\
\hline Fu40_1 & Dinobryon sociale & KJ579304 & \\
\hline Fu40_2 & Dinobryon sociale & KJ579305 & \\
\hline Fu40_4 & Dinobryon sociale & KJ579306 & \\
\hline Fu40_7 & Dinobryon sociale & KJ579307 & \\
\hline Fu40_8 & Dinobryon sociale & KJ579308 & \\
\hline Fu42_6 & Dinobryon sociale & KJ579309 & \\
\hline Fu42_8 & Dinobryon sociale & KJ579310 & \\
\hline
\end{tabular}

Fig. S1. Maximum likelihood phylogeny based on SSU rRNA of the chryosphytes used as a reference tree for the phylogenetic placement of the 454 reads. 160 SSU rRNA gene sequences with 1218 bases were used as references and the maximum likelihood phylogeny was calculated with RAxML 7.2.7 with the General Time Reversible model of nucleotide substitution (STAMATAKIs et al. 2005). 


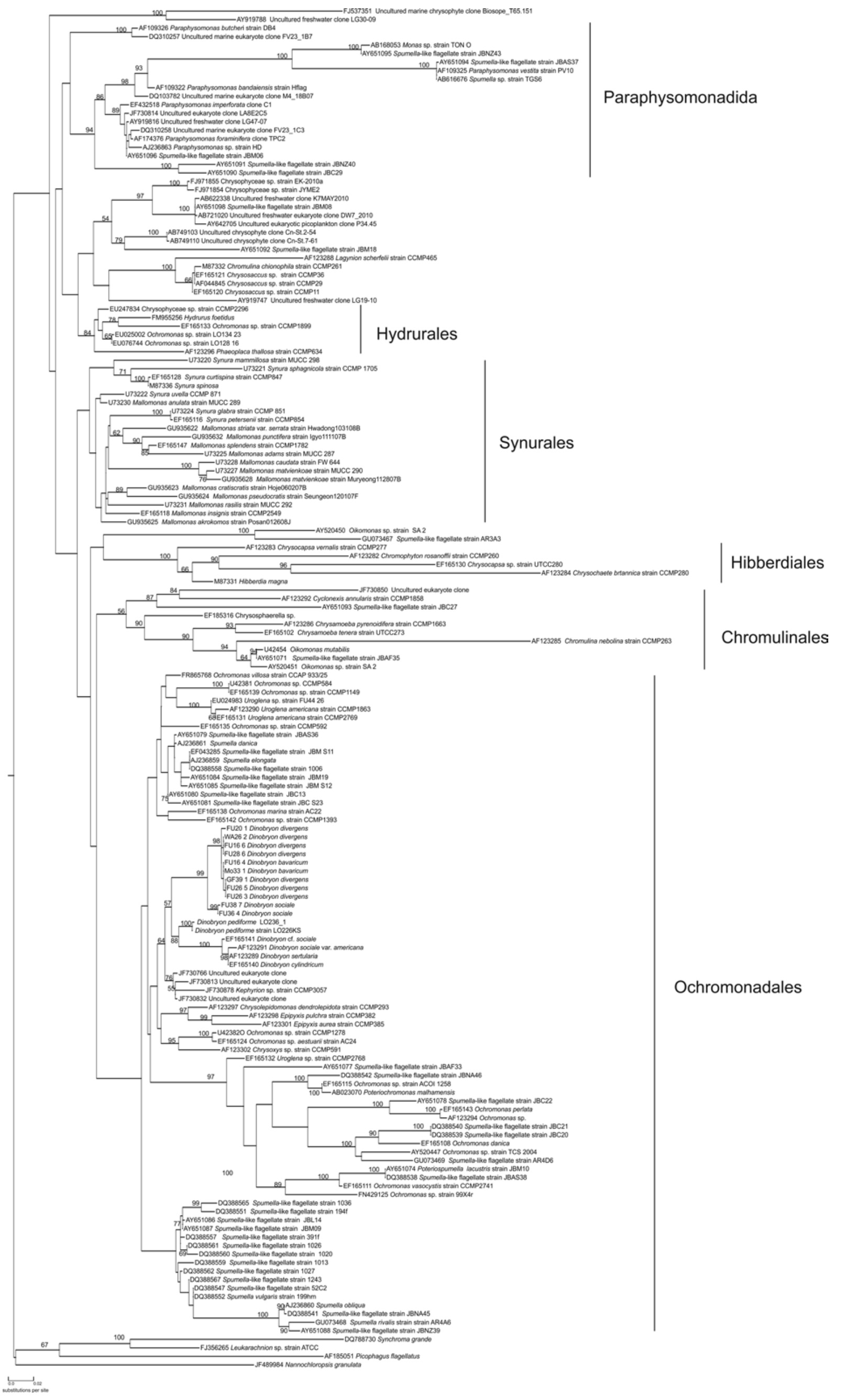




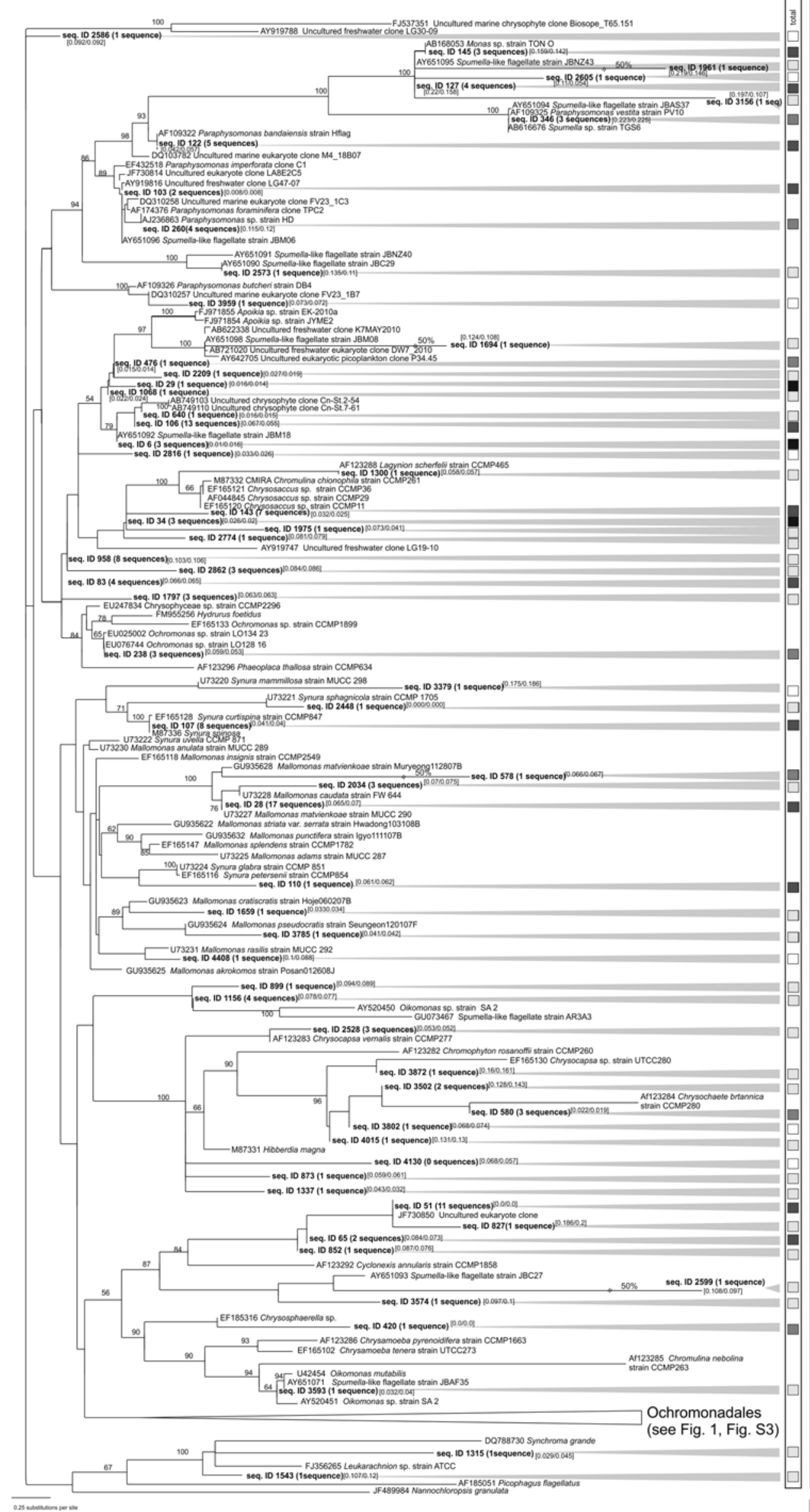

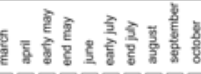

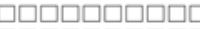

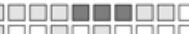

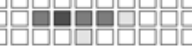

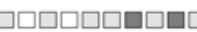

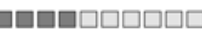

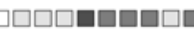

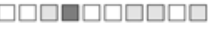

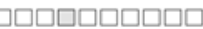

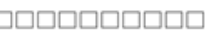

ㅁㅁㅁㅁㅁㅁ ㅁㅁㅁㅁㅁำ 田四国田

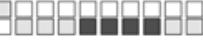

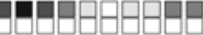
पᄆ口 $\square \square \square \square \square \square$

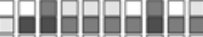

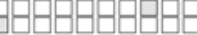

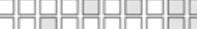

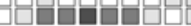
पㅁㅁㅁㅁㄷㅁ ㅁㅁㅁㅁㅁㅁ

$\square \square \square \square \square \square \square \square \square \square$ प्रिम

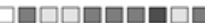

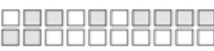
뭄ㅁㅁ

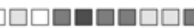

$\square \square \square \square \square \square \square \square \square \square$

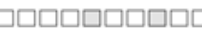

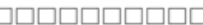

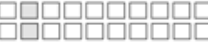
ㅁㅁㅁㅁㅁㄷ مص

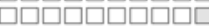

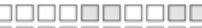
ص पि口 $\square \square \square \square$

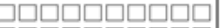
पर

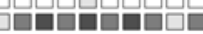

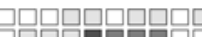

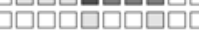
पᄆ口 ㅁㅁㅁㅁㅁㅁ

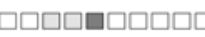
口ㅁㅁㅁㅁ 

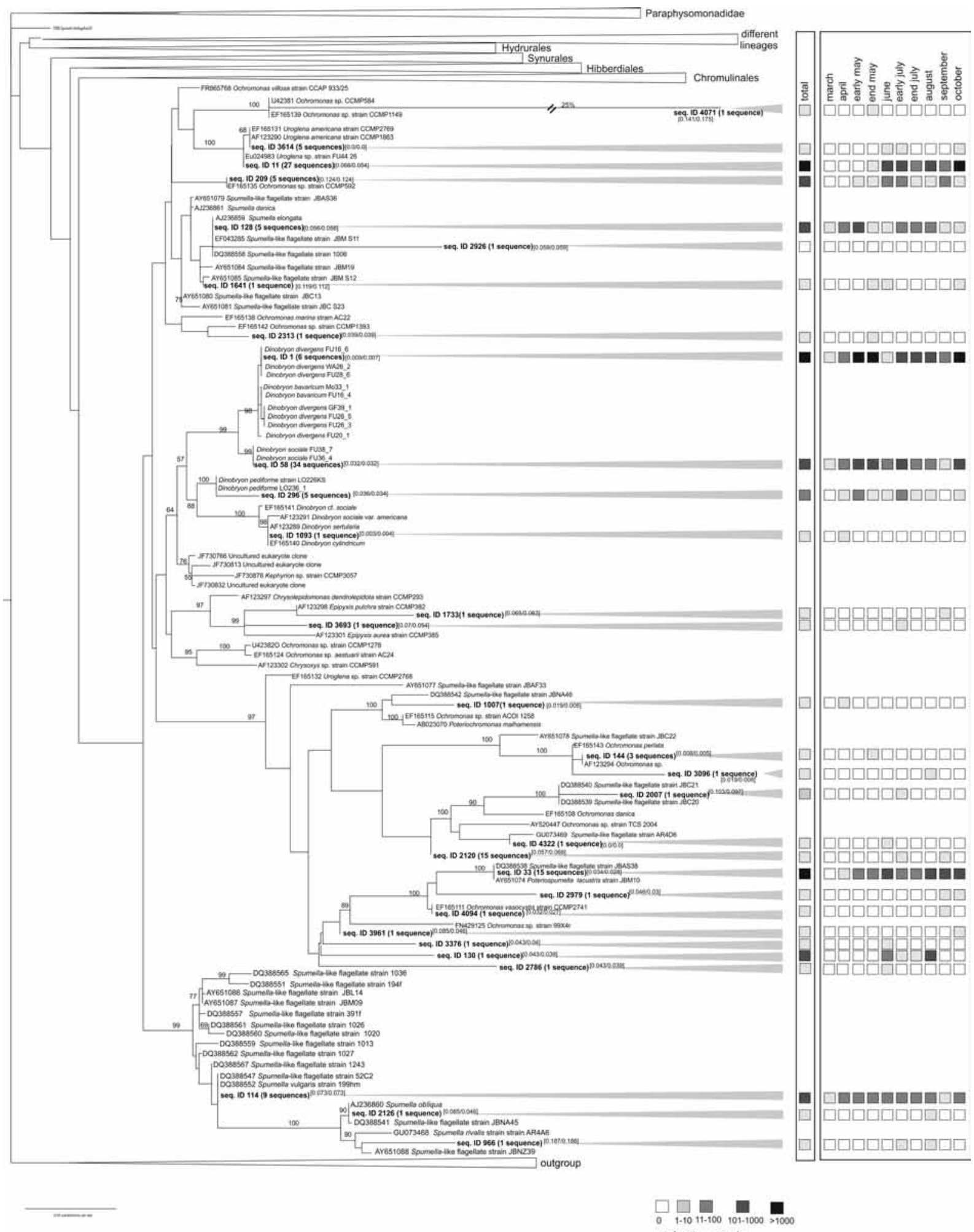

nr. of reads per sample

Fig. S3. The figure shows the Ochromonadales as part of the phylogenetic placement of the 454 reads within the Chrysophyceae (see Fig. S2). The phylogenetic lineages of the remaining clades of the Chrysophyceae are collapsed and shown as triangular boxes.

$\widetilde{\text { Fig. S2. Phylogenetic placement of } 454 \text { reads (293 different sequences, each reads contained approx. 180bp) on a maximum likelihood reference }}$ tree of the Chrysophyceae. 160 SSU rRNA gene sequences with 1218 bases were used as references and the phylogeny calculated with RAxML 7.2.7 with the GTR model of nucleotide substitution (STAMATAKIS et al. 2005). Query sequences were placed on the phylogeny by using pplacer $v 1.1$ (MATSEN et al. 2010). Values in square brackets after the 454 IDs represent the EDPL uncertainty values (first value is based on ML and second value based on Bayesian analyses). Lineages containing solely 454 reads were collapsed on a $99 \%$ pair wise distance threshold. To the right of the tree, the abundance data is summarized into columns of each sample date. The left-most column, "total" contains the sum of all standardized reads, followed by sequence counts for the different sampling dates. The zero abundance of some sequences is a result of the standardization of reads where some rare sequences where not chosen during the process of standardization. The clade of the Ochromonadales was excluded manually due to limited space and is shown in Figure 1 and Fig. S3. 


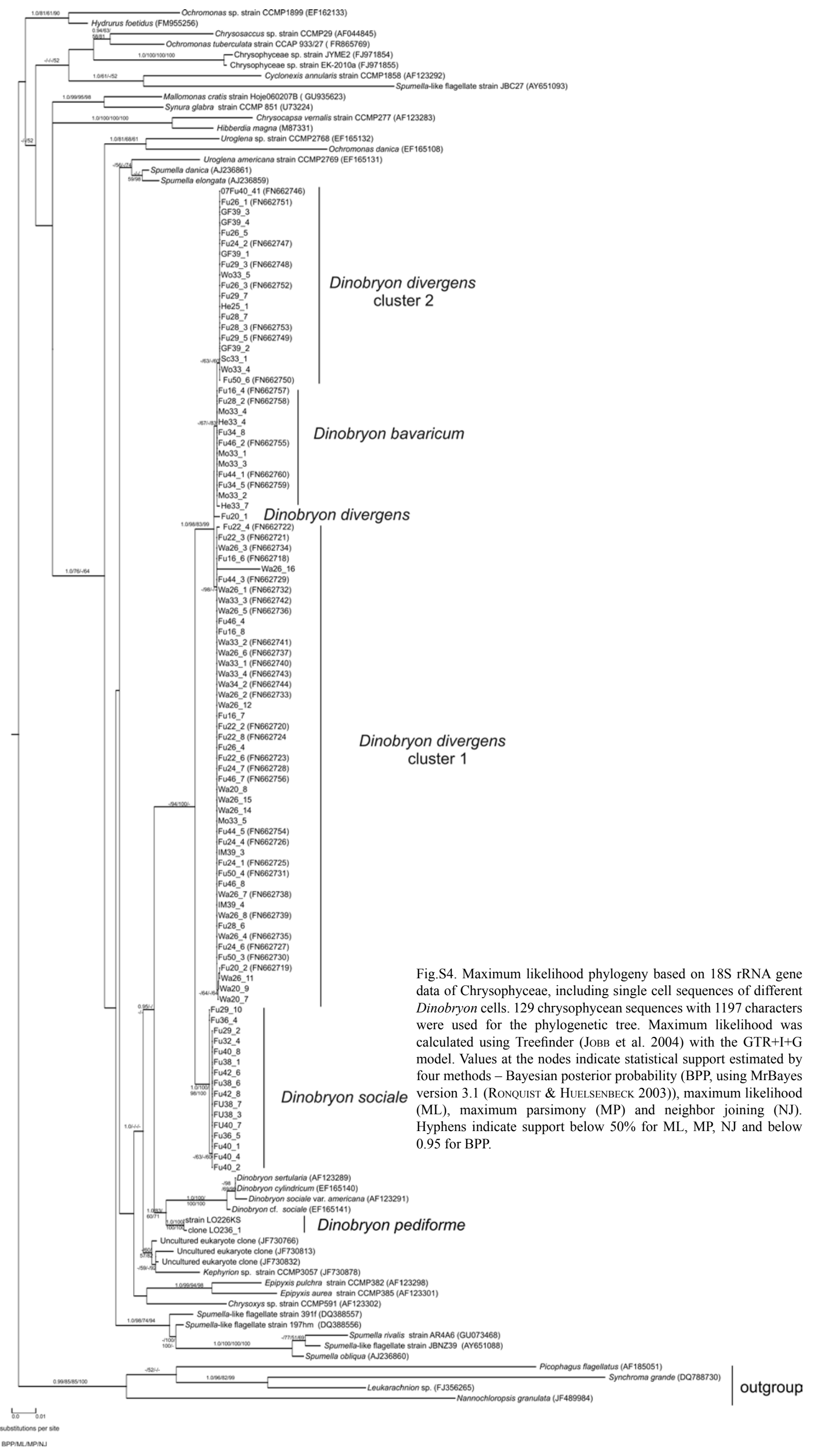




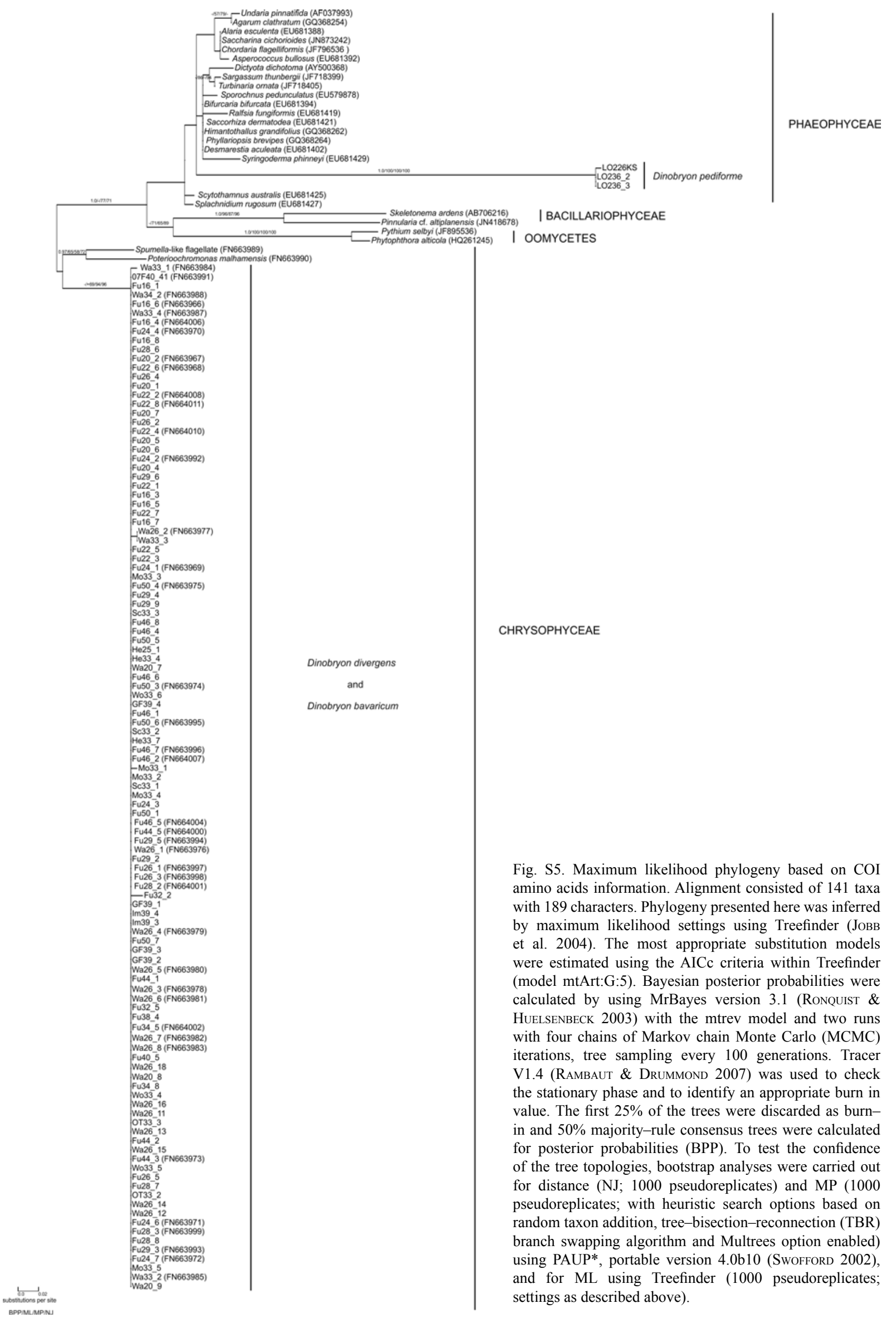

